\author{
Monika Wąchocka \\ Uniwersytet Papieski Jana Pawła II w Krakowie
}

\title{
Łaska w ikonach
}

W Księdze Wyjścia Bóg wyraźnie przemawia słowami: „żaden człowiek nie może ogląadać mojego oblicza i pozostać przy życiu" (Wj 33, 20). Jednakże w swoim miłosierdziu Bóg udziela tej łaski Mojżeszowi, a w późniejszym czasie objawia się ludziom w Tajemnicy Wcielenia swojego Syna. Na podstawie zachowanych do naszych czasów wyobrażeń rzeźbiarskich i ornamentacyjnych starożytnej sztuki Greków widać wyraźnie ich pozytywny stosunek do adorowania posągów różnych bogów, choć w posągach unikano modelowania oczu, by spojrzenie bóstwa nie poraziło oglądających. Trzeba tu odnotować, że w etymologii greckiej słowo eikon (obraz) jest bliskoznaczne słowu eidolon (bożek) ${ }^{1}$. Wydaje się, że pierwotna religia rzymska najprawdopodobniej obywała się bez wizerunków bóstw, ale w późniejszym czasie zwyczaj ten został przejęty od Greków. Ze Wschodu natomiast został przejęty zwyczaj sporządzania wizerunków władców, który służył propagowaniu kultu osoby cesarza. Wyobrażenia władców ulegały dywinizacji, a umieszczane w najodleglejszych rejonach cesarstwa były traktowane jako forma rzeczywistej obecności panującego. Badacze dziejów religii zgodnie dziś twierdzą, że w rejonie basenu Morza Śródziemnego Izrael był jedynym ludem czasów przedchrześcijańskich, który nie posiadał wizerunków Boga w swoim kulcie².

Poglądy na pochodzenie sztuki chrześcijańskiej i na stosunek pierwszego Kościoła do sztuki są różnorodne, a wczesna historia sztuki sakral-

Por. K. Klauza, Teologiczna hermeneutyka ikony, Lublin 2002, s. 121-122.

Por. T. Łukaszuk, Ikona w życiu, w wierze i w teologii Kościoła, Kraków 2008, s. 19. 
nej jest bardzo bogata w wydarzenia, jak choćby kolejne fale ikonoklazmu. Nie da sięjednak zaprzeczyć, że w Kościele obrazy istniały od wieków i trwają obecnie, stanowiąc w wielu wypadkach przedmiot specjalnej czci, co dotyczy głównie obrazów cudownych lub słynących łaskami³. Jakie są więc te łaski, które możemy odnaleźć w ikonach? Odpowiedź na to pytanie wymaga najpierw sprecyzowania pojęcia łaska. Ponadto konieczne jest również przedstawienie drogi, którą przeszła ikona w dziejach sztuki sakralnej. Pochodzenie ikon, ich rozwój oraz znaczenie na przestrzeni wieków pomogą wyjaśnić, jaką rolę ikony pełnią dzisiaj, zarówno w Kościele wschodnim, jak i zachodnim. Podstawową literaturą dla tematyki ikon w ujęciu prawosławnym są dzieła dwóch teologów Kościoła wschodniego: Paula Evdokimova oraz Leonida Uspienskiego. W Kościele zachodnim zagadnieniem tym szczegółowo zajął się Karol Klauza w pracy Teologiczna hermeneutyka ikony, a także o. Tadeusz Dionizy Łukaszuk. Analiza pojęcia i rzeczywistości łaski została zaczerpnięta z opracowań ks. Dariusza Oko oraz niemieckiego teologa Gisberta Greshake'a.

\section{Ogólne znaczenie pojęcia łaski}

Słowo łaska jest współcześnie jednym z najczęściej używanych słów w języku religijnym, i a także jednym z najbardziej nadużywanych. W życiu religijnym i kościelnym posługuje się nim prawie każdy i używa prawie do wszystkiego. W języku potocznym oznacza jakąś energię, którą się posiada, lub którą się utraciło. Poziom tej energii może się powiększać lub zmniejszać, a czasem utracona łaska może zostać odzyskana po spełnieniu określonych warunków. Łaska widziana jest jako szereg sprzyjających życiu ludzkiemu okoliczności, a jednocześnie pozostaje rzeczywistością trudną do opisania. Dzieje się tak, ponieważ nie można otwarcie widzieć łaski, a doświadczenie jej skutków jest trudne do zbadania. Słowo to nabrało więc specyficznego znaczenia, z jednej strony pobożnego, czy nawet magicznego, z drugiej zaś obcego codziennym doświadczeniom.

W odniesieniu do chrześcijaństwa należy stwierdzić, że gdy chodzi o sprawy najistotniejsze w życiu człowieka, czyli o szczęście ostateczne,

Por. tamże, s. 5. 
nie wystarczą same ludzkie dokonania oraz płynące z nich prawo do nagrody. Na drodze do zbawienia potrzebny jest wolny dar pochodzący od Boga, jakim jest możliwość bycia obdarowanym. I właśnie ta rzeczywistość najbardziej oddaje znaczenie terminu łaska ${ }^{4}$.

Łaska jest zatem czymś jak najbardziej boskim, a jednocześnie czymś, co najbardziej określa człowieka. W ludzkim wymiarze jest czymś realnym, nawet obiektywnym, dotyczącym relacji i osoby. Łaska oznacza udzielenie się człowiekowi nieskończonej osobowej istoty, którą jest sam Bóg. Od samego początku więc musi być pojmowana w perspektywie relacji i oso$b^{5}$. Z drugiej strony łaska jako Boża rzeczywistość przekracza wszystko, co można o niej powiedzieć. Zawsze pozostaje dla człowieka tajemnicza i niezgłębiona. Każde zatem słowo o łasce sytuuje go w obszarze tajemnicy $^{6}$. Łaska pozostaje trwałą tajemnicą, tym bardziej że jest wprowadzeniem człowieka w tajemnicę życia Trójcy Świętej, a więc w tajemnicę najbardziej pierwotną. Stanowi więc, obok wcielenia, jedną z trzech największych tajemnic chrześcijaństwa. Trójca Święta, wcielenie oraz przebóstwienie człowieka w łasce i chwale są, jak podkreśla Rahner, tajemnicami w sensie właściwym.

Aby adekwatnie zaprezentować tło dla wczesnochrześcijańskiej sztuki, z której wywodzi się ikona, należy ukazać ówczesny sposób pojmowania łaski zarysowany w chrześcijaństwie wschodnim i zachodnim.

\footnotetext{
Por. G. Greshake, Wprowadzenie do nauki o łasce, przekł. S. Jopek, Kraków 2005, s. 7-11.

Por. D. Oko, Łaska i wolność: łaska w Biblii, nauczaniu Kościoła i teologii współczesnej, Kraków 1998, s. 175-176.

Por. tamże, s. 164. Należy jednak pamiętać, że tajemnica w sensie ścisłym, jak zaznacza Rahner, „nie jest czymś jeszcze nieodsłoniętym, co stoi jako coś drugiego obok czegoś już pojętego i przejrzanego. Przy takim rozumieniu pojęcie tajemnicy byłoby zamienione z pojęciem czegoś jeszcze nieodkrytego, niepoznanego. Tajemnica jest o wiele bardziej tym, co właśnie jako nieprzejrzewalne jest tutaj, jest dane, wcale nie jest przeznaczone do usunięcia, zniknięcia, nie jest czymś wtórnym, tylko tymczasowo nierozwikłanym. Ona jest właśnie dana jako nieopanowywalnie panujący horyzont wszelkiego pojmowania, który wszystko inne pozwala pojmować, podczas kiedy on sam - niepojęcie istniejący - siebie samego zamilcza. Tajemnica nie jest więc czymś tymczasowym, co zostaje usunięte albo co w sobie mogłoby być inne, ale jest własnością, która zawsze charakteryzuje Boga (a przez niego także nas). Tak bardzo, że bezpośrednie oglądanie Boga, które jest nam przyrzeczone jako nasze ostateczne spełnienie, jest bezpośredniością niepojmowalności, a więc jest właśnie zniknięciem złudzenia, jakobyśmy tylko tymczasowo nie wniknęli całkiem w tę niepojmowalność; bo w tym oglądaniu będzie on sam widziany, a nie tylko nieskończone ubóstwo naszej transcendencji, dla której on jest niepojmowalny"- tamże, s. 164-165.
} 


\section{Łaska we wczesnej teologii wschodniej}

W teologii Wschodu zasadniczą treścią był biblijny sposób rozumienia łaski jako całego działania Boga wobec człowieka. Nie istniała w takim stopniu jak na Zachodzie, różnica pomiędzy naturą i łaską, stworzeniem i zbawieniem. W związku z tym nie była znana żadna specjalna rzeczywistość łaski, a tym bardziej różne jej rodzaje. Dla wczesnej teologii Wschodu łaska oznacza sposób, w jaki Bóg współdziała ze światem i działa w nim, zarówno w aspekcie całego chrześcijaństwa czy wiary, jak i określonych momentów życia Kościoła bądź pojedynczego człowieka.

Wschodnia teologia osadzała rozumienie łaski w biblijnym określeniu człowieka jako obrazu Bożego. „Człowiek - obraz Boga” był zasadniczą , ,definicją" człowieka, która nadawała ton rozumieniu działania zbawczego Boga. Dar bycia obrazem Boga został udzielony człowiekowi w sposób zaczątkowy w akcie stworzenia, a przez grzech został zniekształcony. Działanie zbawcze Boga miało więc na celu uwolnić człowieka - obraz Boży od zepsucia grzechu i uformować go z możliwie największym podobieństwem do Boga. Celowi temu miał służyć proces wychowawczy, przez który ojcowie apostolscy rozumieli całą historię zbawienia: od momentu stworzenia, poprzez wydarzenia historyczne, aż do objawienia się Syna Bożego w ciele. Jezus Chrystus jest punktem szczytowym tego wychowawczego działania Boga; ale proces ten jest kontynuowany przez działanie Ducha Świętego oraz Kościól. Sposób boskiego wychowania polega na pozyskaniu ludzkiej wolności. Człowiek powinien powiedzieć w sposób wolny „tak” wyższej wolności w Chrystusie. Wizja zbawienia w greckiej patrystyce uwypukla ludzką wolność, gdyż właśnie ona jest specyfiką bycia Bożym obrazem. Celem tego wychowawczego procesu zbawczego jest „,przebóstwienie” człowieka. Jest to zasadnicza idea wschodniej teologii zbawienia. Bóg staje się człowiekiem, aby człowiek stawał się Bogiem. W tym procesie inicjatywa jest po stronie Boga, a człowiek w swojej wolności powinien ją przyjąć i na nią odpowiedzieć.

Z tej perspektywy jest rzeczą zrozumiałą, że we wczesnej teologii greckiej w zasadzie nie było szczególnej nauki o łasce, a raczej całe zbawcze działanie Boga było rozumiane jako łaska. Od tej koncepcji wyraźnie odbiega rozumienie łaski w Kościele zachodnim7.

Por. G. Greshake, Wprowadzenie..., dz. cyt., s. 30-61. 


\section{Łaska we wczesnej teologii zachodniej}

Zachodnie chrześcijaństwo od samego początku znajdowało się w innym kontekście socjokulturowym niż wschodnie. 0 ile teologia wschodnia brała pod uwagę cały kosmos jako jednolitą i harmonijną całość, o tyle teologowie zachodni skłaniali się bardziej ku zagadnieniom praktycznych konkretnej drogi życiowej pojedynczego człowieka oraz do polityczno-prawnej formy życia wspólnego. W centrum zainteresowania znalazło się więc pytanie o odpowiedzialność, winę i nagrodę. Chrześcijaństwo na Zachodzie nie było rozumiane jako pedagogia, lecz jako religia boskiego prawa, jako uzasadnienie i realizacja nowej, prawnej relacji pomiędzy Bogiem i człowiekiem. Wydarzenie zbawcze widziane było bardziej z punktu widzenia pojedynczego człowieka i jego potrzeb, a zadawane pytania dotyczyły sposobu osiągnięcia zbawienia. Wobec takich założeń odpowiedzią była pomoc łaski, pojmowana jako jedna ze szczególnych boskich mocy, która jest przekazywana przez Chrystusa. Tak rozumiana łaska miała uwalniać od grzechu i pozwalać człowiekowi dążyć w zamierzonym kierunku. W teologii zachodniej zatem nie wszystko było łaską, a jedynie to, co niezależnemu człowiekowi musiało być dodane, by stał się naprawdę wolny: najpierw od grzechu, a następnie do spełnienia samego siebie ${ }^{8}$.

\section{Pojęcie ikony - droga poprzez słowa i czyny}

Każda sztuka jest sposobem wyrażania myśli, swoistym językiem ekspresji, którego elementy odnoszą się do sensu dokładnie tak samo, jak słowa odnoszą się do myśli wyrażanej przez zdanie9. Tak więc jak niektóre słowa i zdania wyrażają modlitwę, tak i w sztuce znajdujemy obraz będący modlitwą. Ikona wyraża rzeczywistość oznaczaną przez system znaków i symboli, dzięki czemu jest poznawalna w sposób obiektywny, a nie tylko subiektywny. W wymiarze religijnym, na gruncie teologii ikona posiada wartość poznawczą porównywalną ze słowem ${ }^{10}$.

Tamże, s. 30-61.

Por. P. Evdokimov, Sztuka ikony. Teologia piękna, przeł. M. Żurowska, Warszawa 1999, s. 185.

Por. K. Klauza, Teologiczna..., dz. cyt., s. 15. 
Jak podaje Karol Klauza, „poprzez ikonę w szerokim sensie tego pojęcia rozumiemy każde materialne przedstawienie idei religijnej. W sensie ścisłym zaś będzie to każde przedstawienie plastyczne - malarskie, rzeźbiarskie i architektoniczne, wykonane dowolną techniką i odniesione do kontekstu religijnego"11.

Ikona powstaje w określonym czasie i przestrzeni, jako przedmiot wyższej kultury duchowej, uczyniony dla konkretnej religijnej grupy społecznej. Stąd w badaniu i rozpoznawaniu ikon istotne jest, by uwzględnić okoliczności czasu, miejsca i kontekstu kulturowego, w jakich powstała. Ponieważ ikona dotyczy przestrzeni zarówno materialnej, jak i duchowej, należy pamiętać, że jej strona materialna stanowi przedmiot poznania zmysłowego i rozumowego, a duchowa odkrywana jest wiarą na drodze kontemplacji ${ }^{12}$.

Nazwa „ikona” wywodzi się z greckiego słowa eikon (jak podaje Evdokimov, pochodzącego od eiko - podobieństwo, analogia ${ }^{13} \mathrm{i}$ w dziedzinie sztuki religijnej posiada dwa znaczenia. Po pierwsze, mieszkańcy Bizancjum nazywali tak każde figuralne przedstawienie Chrystusa, Najświętszej Maryi Panny lub świętych, niezależnie od techniki wykonania i użytego materiału. Dopiero późniejszy Kościół prawosławny zastrzegł ten termin wyłącznie dla malowideł na desce drewnianej wykonanych specjalną techniką zgodnie z przekazywanymi przez wieki regułami, stanowiącymi tak zwany kanon ikonograficzny ${ }^{14}$.

\section{Znaczenie ikony w Kościele Wschodnim}

Ikona będąca przedmiotem kontemplacji ze swojej natury jest określana jako okno ku wieczności ${ }^{15}$. W teologii wschodniej uważa się, że ikona sięga w tajemnicę Boga głębiej niż słowo. Dzieje się tak dlatego, że obraz Boga zakorzeniony jest w Jego istnieniu. Stąd Boże imię wyrażające Jego naturę - „Jestem - Który - Jestem” (Wj 3, 14) wskazuje na obraz, choć zo-

11 Tamże, s. 15.

12 Por. tamże, s. 80.

13 Por. P. Evdokimov, Sztuka ikony..., dz. cyt., s. 168.

14 Por. T. Łukaszuk, Ikona..., dz. cyt., s.7.

15 Pojęcie to znane jest powszechnie w ikonologii teologicznej, więcej na ten temat: M. Quenot, Ikona. Okno ku wieczności, przeł. H. Paprocki, Białystok 1997. 
stało wyrażone poprzez słowo ,jest”. Zatem tak jak słowo należy do sfery Boskiego działania, tak obraz należy do sfery Boskiego istnienia ${ }^{16}$.

Najpełniejszy zarówno wyraz, jak i obraz Boga został wyrażony w świecie człowieka poprzez tajemnicę wcielenia Syna Bożego. Na poziomie intelektualnym w wydarzeniu tym jesteśmy w stanie dostrzec połączenie rzeczywistości nadprzyrodzonej i stworzonej, wiecznej i czasowej, duchowej i materialnej, indywidualnej i trynitarnej - bez żadnej przerwy, zmieszania czy wydzielenia. Pełny sens tajemnicy wcielenia przekracza jednak zdolności poznawcze człowieka. Pozostaje ona jako horyzont wiary, będący zawsze przed człowiekiem w sferze myśli. Stąd pomocny ludzkiej naturze jest obraz, który wyraża tę tajemnicę nie mniej skutecznie niż słowo. Przedwieczny Logos, który „stał się człowiekiem”, to także ikona Ojca ${ }^{17}$.

Istotnym zadaniem ikony jest umożliwienie człowiekowi spotkania z Bogiem. W powiązaniu z Verba et gesta Christi ikona staje się jednym z takich miejsc, w którym ludzkie działania dotykają sacrum. Świętość nie wynika jednak w sposób konieczny bezpośrednio z ludzkiego działania, jednakże każdy czyn stwarza sprzyjającą okoliczność dla uświęcenia przychodzącego od Boga daru łaski. Ponieważ ikona jest miejscem spotkania Boga z człowiekiem, niesie ze sobą nie tylko Bożą obecność, ale także Boże działanie. Łaska jest tą rzeczywistością, która nie istnieje ani bez dawcy, którym jest Bóg, ani bez odbiorcy, którym jest człowiek ${ }^{18}$. Każdy człowiek, niezależnie od czasu, w którym żyje, i przestrzeni, w której przebywa, stanowi potencjalne miejsce udzielenia łaski, rozumianej jako ubogacające spotkanie osób, które znajdują się w pełni życia, czyli w sacrum. Tak właśnie dzieje się z ikoną ${ }^{19}$. Każde takie spotkanie Boga i człowieka ma wpływ na całe stworzenie, gdyż stanowi element budowania Królestwa Bożego w świecie. W teologii inkarnacyjnej ikona realizuje swoje przeznaczenie w procesie poznawczym - Bóg jest ukazywany w postaci ludzkiej oraz w aspekcie moralnym, ukazując wzór służący upodobnieniu człowieka do Boga.

Dla chrześcijańskiego Wschodu ikona jest przede wszystkim obiektem kultu. Na plan dalszy przesunięty jest jej aspekt historyczny czy artystyczny.

\footnotetext{
16 Por. K. Klauza, Teologiczna..., dz. cyt., s. 25.

17 Por. tamże, s. 26-27.

18 Por. T. Łukaszuk, Ikona..., dz. cyt., s. 91.

19 Por. K. Klauza, Teologiczna..., dz. cyt., s. 91-92.
} 
Cześć dla świętych ikon wpisana jest niezbywalnie we wschodnią pobożność. Ikony nie stanowią tam dekoracyjnego elementu miejsc kultu ani środka do pouczenia czy zbudowania religijnego w taki sposób, w jaki dzieje się to w pobożności zachodniej. Wierni Kościoła wschodniego wierzą, że ikony przedstawiają im ostateczny cel stworzonego świata oraz są manifestacją tej siły, która stopniowo przekształca człowieka w świątynię Ducha Świętego. Ikony uzmysławiają pewność wiernych co do tego, że ich ziemska pielgrzymka jest podążaniem do stanu szczęśliwości i miłości w Bogu ${ }^{20}$.

Ikony w Kościele wschodnim mają duże znaczenie nie tylko w kulcie publicznym, ale także w życiu prywatnym wiernych. Podstawowymi miejscami dla ikony są kościół $i$ klasztor, jednakże spotyka się je również w domach prywatnych. W kościele ikony umieszczane są przede wszystkim w ikonostasie, natomiast w domach w specjalnie przeznaczonym miejscu, tzw. „świętym zakątku" ${ }^{21}$. Tradycja prawosławna związana z ikoną przenika każdy element życia wiernych. W momencie narodzin czy śmierci wręczano rodzinie ikony przedstawiające świętych patronów. $W$ prezencie ślubnym młodej parze wręczano ikony ślubne, z których jedna przedstawia Chrystusa Pantokratora, a druga Matkę Bożą z Dzieciątkiem, najczęściej przedstawioną jako Eleusa (Miłosierna), ale także jako Hodegetria (Wskazująca drogę). Ikony podróżne to typ miniaturowych ikon oprawionych w taki sposób, by nie uległy zniszczeniu w czasie podróży; zgodnie z tradycją chrześcijanie zabieralije ze sobą $\mathrm{w}$ drogę. Cesarze bizantyńscy zwykli obdarowywać ikonami dostojnych gości lub zasłużonych dla państwa urzędników, przy czym należy zaznaczyć, że dary te zawsze miały charakter religijny, były ofiarowywane jako życzenie łaski Bożej, a nie tylko wysokiej wartości dzieło malarskie ${ }^{22}$.

\section{4. Święty obraz w Kościele zachodnim}

W zachodnim kręgu kulturowo-religijnym słowo „ikona” było rzadko używane. Mówiono tutaj raczej o świętych obrazach (sacrae imagines) i ich kulcie, mając na myśli znaczenia podobne do tych, które występu-

20 Por. T. Łukaszuk, Ikona..., dz. cyt., s. 8.

${ }^{21}$ Por.tamże, s. 10.

22 Por. tamże, s. 9. 
ją w myśli wschodniej w odniesieniu do ikony. Dotyczyło to głównie tych obrazów, które były szczególnie czczone i znane pod nazwą obrazów cudownych lub słynących łaskami. Obrazy te nie zawsze odpowiadały wszystkim wymogom kanonu ikonograficznego, jaki powstał i obowiązywał na Wschodzie, ale spełniały podobną rolę jak ikony. Obrazy te istnieją w życiu religijnym wiernych i w publicznym kulcie Kościoła. Ich funkcja zbliża je bardzo do pojęcia ikony i w pewien sposób pozwala na łączne traktowanie obu tych rzeczywistości ${ }^{23}$.

Wykorzystanie obrazu jako środka służącego do przekazania prawdy i łaski pojawiło się w życiu Kościoła wraz z zastosowaniem symboliki gestu i znaku. Sztuka wczesnochrześcijańska traktowała obraz w kategoriach świadectwa dawanego prawdzie, włączając $w$ to aspekt rezerwy pierwszych chrześcijan do jakichkolwiek wyobrażeń malarskich ze względu na obawę przed bałwochwalstwem. $Z$ upływem czasu zostały jednak dopuszczone najpierw symbole, a później malarstwo religijne, zawsze jednak jako narzędzie do ukazania Chrystusa i świętych ${ }^{24}$.

W praktyce jednak ikonoklastyczne spory VIII i IX wieku potwierdziły rozejście się obu tradycji. Nurt rzymski zajął stanowisko, które głosiło, że „,ikony wyrażają to, co niewidzialne; są one jednak jedynie wyrazem pośrednim, na zasadzie związku postrzeganego duchem między przedstawianymi modelami a ich modelunkiem w rzeczach. Malarstwo dogmatyczne jest swoistym dodatkiem, dopełnieniem z punktu widzenia oczywistości; nie może być ono oddzielane od wiary, która uczy nas jedności niewidzialnego z widzialnym. Wschód, przyjmując to rozróżnienie, poszedł w kierunku zachowania i mocniejszego akcentowania obecności przez ikonę wyobrażanego modelu. Funkcję doktrynalną zapewniać miały szczegółowe przepisy wykonywania ikon i otaczania ich wyrazami czci i atmosferą modlitwy"25.

We współczesnej teologii zachodniej orzeczenia Soboru Watykańskiego II ${ }^{26}$, które uświadomiły sens obecności Chrystusa w liturgicznej lekturze słowa Bożego, w konsekwencji pomogły zauważyć podobne działanie w przypadku ikony. Szczególnie pomocne okazało się w tym przypadku doświadczenie

\footnotetext{
23 Por. tamże, s. 7-8.

24 Por. K. Klauza, Teologiczna..., dz. cyt., s. 88.

25 Por. tamże, s. 140.

26 Sobór Watykański II, konst. Sacrosanctum Concilium, rozdz. VII.
} 
chrześcijaństwa wschodniego, w którym kwestia obecności przedstawionej postaci $\mathrm{w}$ ikonie pozostała niezmiennym elementem liturgii ${ }^{27}$. Precyzując kryteria oceny dzieł sztuki, Sobór Watykański II opowiedział się za badaniem zgodności obrazu z depozytem wiary i praktyki Kościoła.

\section{5. Łaska płynąca z ikony}

Poza stroną materialną ikona związana jest ściśle z treścią, którą niesie. Tak jak to zostało już wcześniej zaznaczone - jest swoistym sposobem przepływu łaski Bożej. Poprzez ikonę jesteśmy w stanie poznać główne prawdy wiary, takie jak na przykład preegzystencję Logosu, łaskę narodzenia Pańskiego, przemienienia, zbawczą mękę, tajemnicę zmartwychwstania, a także zstąpienie do piekieł czy wniebowstąpienie. Dopełnieniem tej łaski poznania płynącej z ikony dla wiernych obu Kościołów jest Eucharystia, która w obu rytach pozwala na osobiste spotkanie człowieka z Bogiem i obdarowanie pełnią łaski ${ }^{28}$.

Pierwszym i najbliższym człowiekowi przejawem łaski płynącej z ikony jest dar modlitwy. Dzieje się tak, ponieważ ikona, podobnie jak słowo, domaga się od człowieka odpowiedzi. W życiu Kościoła będzie to przede wszystkim postawa wiary w poznaną w ikonie prawdę. Wiara zaś daje możliwość nie tylko spotkania Boga z człowiekiem, ale również dialogu. Natomiast wchodząc w dialog z Bogiem, człowiek odwzorowuje w sobie istotne elementy „bycia obrazem Boga”. Można więc powiedzieć, że ikona jako szczególne miejsce teologiczne jest również pewnego rodzaju szkołą modlitwy wprowadzającą w świat Bożych treści ${ }^{29}$.

Z teologicznego punktu widzenia w Jezusie Chrystusie, który jest archetypem każdej osoby ludzkiej, odnajdujemy drogę i szansę przebóstwienia człowieka, zniszczonego poprzez grzech. Proces ten, dokonujący się dzięki Duchowi Świętemu, jest tajemnicą samoudzielania się Boga, czyli tajemnicą łaski. Tę rzeczywistość również jesteśmy w stanie poznać dzięki ikonie, ze względu na jej kontekst inkarnacyjny. W Kościele wschodnim ikona jest jednym z sakramentów, a dokładniej rzecz biorąc - sakramentem oso-

27 Por. K. Klauza, Teologiczna..., dz. cyt., s. 92.

28 Por. tamże, s. 93.

29 Por. tamże, s. 153. 
bowej obecności ${ }^{30}$. W Kościele zachodnim ikona nie stanowi rzeczywistości sakramentalnej, a fakt uobecniania ma charakter analogiczny względem Eucharystii. Niemniej jednak można stwierdzić, że dzięki ikonie tak jak dzięki słowu Ewangelii realnie dokonuje się spotkanie Boga z człowiekiem, a więc natury ludzkiej z Bożą nadprzyrodzonością, ułomności ze świętością, czasu $\mathrm{z}$ wiecznością Boga. W ramach tego communio sanctorum człowiek staje się uczestnikiem darów wiecznych oraz odbiorcą wszelkich Bożych działań uświęcających. Po takim spotkaniu odchodzi on sprzed ikony z poczuciem odnowienia wiary, pokory i świętości ${ }^{31}$.

Drugim aspektem łaski płynącej z ikony jest uzdrowienie duchowe. Ikonę znów można tutaj porównać do Eucharystii, ze względu na skutki, jakie niosą obie te rzeczywistości. Chodzi tu bowiem o wezwanie człowieka do przemiany życia, do metanoi postępowania oraz do wysiłku upodobniania się do Chrystusa. Ikona bowiem ukazuje ideał, ku któremu ma zmierzać wszelki ludzki wysiłek pozbywania się grzechu i umacnianiu w dobru. Proces doskonalenia moralnego określany w języku teologicznym jako walka z jednej strony oznacza nabywanie cnót, z drugiej zaś wskazuje na potrzebę bycia czujnym, by móc przeciwstawić się pokusom i grzechowi jako największym zagrożeniom dla kształtowania człowieka na żywą ikonę Boga. Także i w tym przypadku ma to znaczenie nie tylko indywidualne, ale także społeczne.

Ikona jako „okno ku Bogu” jest znakiem świata innego i nieustannie nowego. W każdej płaszczyźnie jest żywym kontrastem wobec przemijającego świata ludzkiego. Trzeba jednak stanąć wobec ikony z pragnieniem oglądania Boga oraz nowego nieba i nowej ziemi. Istota Boga i Jego tajemnice są niepoznawalne na drodze czysto rozumowej, stąd modlitwa kontemplacyjna poprzez niejako zmuszenie do milczenia oraz wyzwolenie od pojęć pozwala zbliżyć się do tych tajemnic. Jednakże aby stało się to możliwe, trzeba przyjąć dary Ducha Świętego przygotowujące do widzenia spraw Bożych w pełnym świetle. W praktyce oznacza to odkrywanie w ikonie jej przesłania, które kształtuje świadectwo życia i czyni z człowieka żywą ikonę na wzór przedstawianych Bożych postaci² ${ }^{32}$.

30 Materią sakramentu ikony jest jej podobieństwo do pierwowzoru. Por. P. Evdokimov, Sztuka..., dz. cyt., s. 156.

31 Por. K. Klauza, Teologiczna..., dz. cyt., s. 153-154.

32 Por. tamże, s. 163-164. 


\section{6. Łaska pisania ikony}

Już sama geneza ikony ma kontekst modlitewny. Przede wszystkim przed jej napisaniem twórca kieruje do Boga słowa modlitwy, prosząc o łaskę, by została oświecona jego dusza, serce i umysł, a dłonie pokierowane do jak najwierniejszego oddania podobieństwa Bożego wizerunku. Ponadto sam proces tworzenia ikony staje się osobistą modlitwą, doświadczeniem łaski poprzez rozumienie, widzenie i przestawanie z tajemnicami Bożymi. Tej kontemplacji twórcy odpowiada późniejsza postawa kontemplacji odbiorcy ikony. Kontemplacja bowiem stanowi naturalne środowisko ikony ${ }^{33}$.

Na gruncie rozumienia ikony jako dzieła ludzkiego zamykającego w sobie doświadczenie wiary i odkrycie Boga mamy do czynienia przede wszystkim z przedmiotem materialnym, wykonanym przez człowieka, ale posiadającym swoje odniesienie do świata duchowego. Stąd ikona, wskazując na rzeczywistość przekraczającą swojego twórcę, wiąże w sobie ludzki świat materialny z duchowym aspektem ,świata” Boga. Ponieważ ikona jest miejscem, w którym niebo łączy się z ziemią, rola ikonografa pozostaje niebagatelna. Jego zadaniem jest nie tyle ukazać tajemnicę przy użyciu farby, ile odsłonić jej prawdę z mitycznych i zbędnych naleciałości. Ikonę cechuje wybitny schematyzm, który umożliwia wkroczenie w światło teofanii ${ }^{34}$.

Sztuka sakralna ikony poprzez swoją prostotę nie wyzwala emocji, lecz zmysł mistyczny. Sam artysta pozostaje ukryty za Tradycją i Kanonem, które tworzą podstawę do poprawnej interpretacji teologicznej ikony. Ten zbiór przepisów jest wyrazem troski o prawdę przekazu. Religijna funkcja ikony dyktowała szereg szczegółowych przepisów wykonawczych, a praktykę tę powierzano wybranym przez Kościół osobom. Dzięki tej praktyce aż do czasów współczesnych możliwa jest prawdziwa teofania. W kulturze zachodniej wspomnienie nie jest - tak jak to ma miejsce na Wschodzie - wspomnieniem epifanicznym. Jednakże każdy człowiek, który przychodzi przed ikonę tylko jako obserwator, odczuwa, że nie jest ona zwykłym dziełem sztuki, ale aktem uwielbienia i modlitwy ${ }^{35}$.

\footnotetext{
33 Por. tamże, s. 154-155.

34 Por. tamże, s. 147.

35 Por. P. Evdokimov, Sztuka..., dz. cyt., s. 157.
} 
Św. Jan Damasceński, mówiąc o ikonie, stwierdził, że „ikonę uświęca imię Boże i imię przyjaciół Boga (świętych), i dlatego otrzymuje ona łaskę Bożego Ducha" ${ }^{36}$. W świetle Biblii imię Boże jest jednym z miejsc Bożej obecności, a ikona jest imieniem nakreślonym. Dojrzewająca w teologii świadomość rangi ikony wymagała wiedzy teologicznej i głębokiego życia wewnętrznego, pozwalającego na ogląd spraw Bożych za pośrednictwem albo przy okazji przestawania z ikonami. Teologiczna interpretacja ikony i kanony jej tworzenia wymagają wykorzystywania wiedzy teologicznej oraz orientacji w samej ikonografii. Oprócz norm typowo kościelnych istotna jest historia ikony, znaczenie stosowanych symboli oraz tradycyjna technika wykonania ${ }^{37}$.

Sztuka świecka przestrzega praw optycznych, które porządkują rzeczy, by stworzyć spójną wizję wymiaru pozaziemskiego. Chcąc uzyskać wyraz, ustanawia ona jedność akcji i perspektywy. Sztuka ta tworzy punkt widzenia pełen optycznej iluzji, potrzebnej do jak najbardziej naturalistycznego przedstawienia osób czy przedmiotów. W porównaniu ze sztuką realistyczną użyteczną w życiu codziennym ikona nie kopiuje natury, dlatego nie ma w niej zależności pomiędzy rzeczywistością a tym, co wieczne, zarówno pod względem czasu, jak i przestrzeni.

To, co dotyczy czasu, w ikonie można streścić jednym zdaniem: tu chronologia nie istnieje, bowiem zestawienie scen odpowiada wewnętrznemu porządkowi czasu odkupionego. Wydarzenia są ze sobą powiązane w zależności od ich sensu i duchowych wymagań, a nie z historyczną dokładnością. Ikona nigdy nie jest „oknem na naturę" ani na konkretne miejsce, lecz zdecydowanym otwarciem na wymiar pozaziemski, oświetlony tajemnicą Ósmego Dnia ${ }^{38}$. Część narracyjna ikony wyrażona jest za pomocą ścisłego minimum przypomnienia. Przykładem mogą być tu wizerunki męczenników, którzy nie niosą narzędzi swojej męki, gdyż są już poza historią ziemską. Jeśli zaś chodzi o perspektywę w ikonografii, często zostaje ona odwrócona: punkt zbiegu nie znajduje się w centrum obrazu, lecz niejako przed nim. Zabieg ten daje efekt zbliżenia do obserwującej ikonę

36 Św. Jan Damasceński, Patrologia graeca, 94, 1256.

37 Por. K. Klauza, Teologiczna..., dz. cyt., s. 148-149.

38 Ósmy Dzień - w teologii prawosławnej zarazem pierwszy i ósmy dzień tygodnia, dzień światłości, czas celebrowania Eucharystii; symbol antycypacji życia wiecznego. Por. E. Smykowska, Liturgia prawosławna, Warszawa 2008 (Mały Słownik). 
osoby i włączenia jej w wydarzenia na ikonie przedstawione. Świat ikony zwraca się w ten sposób ku człowiekowi ${ }^{39}$.

Zewnętrzna forma ikony jest więc prosta, unika naturalizmu, estetyzacji. Jej piękno pochodzi nie z harmonii natury stworzonej, lecz Boskiego piękna przenikającego przedstawiane postaci niejako z wnętrza ikony. Uzyskanie takiego efektu w ikonie nie tylko zależy od Bożego przebóstwienia osoby piszącej ikonę, ale także od obowiązujących zasad, czyli zebranych w kanon dobranych symboli i dopełnienia słownego. Do kanonu tego należą między innymi takie zasady, jak: frontalne ukazanie osoby, dzięki któremu uzyskuje się efekt relacji pomiędzy przedstawioną postacią a oglądającym. Możliwości tej brakuje w przedstawieniach profilowych, w których z natury trudno spotkać spojrzenie przedstawionej postaci, co kieruje raczej ku nieobecności niż szansie spotkania. Ikonograf układa kompozycję ikony, kierując ją wzwyż, a nie w głąb, a odpowiednie rozmieszczenie poszczególnych elementów wyklucza horror vacui - lęk przed pustką. Wrażenie odległości zostało uzyskane przez odpowiednie zestawienie kolorów i jasnych plam na płaskiej powierzchni, a wrażenie ruchu - prze złote tło, układ ciał lub - tak jak w przypadku mozaiki - światło odbijane przez poszczególne jej elementy ${ }^{40}$.

Na ikonach nigdy nie przedstawia się źródła światła, gdyż światło stanowi ich temat - „nikt nie oświetla słońca” ${ }^{41}$. Istnieje przekonanie, że kontemplacja ikony Przemienienia uczy każdego ikonografa, by do malowania używał o wiele więcej światła niż barw. W języku techniki malarskiej złote tło ikony nazywa się światłem, a metodę pracy - stopniowym rozjaśnianiem. Polega ona na pokryciu ciemną barwą całego lica ikony, a następnie wydobywania wizerunku z każdą następną warstwą farby przy użyciu barw coraz jaśniejszych. Światłocień czy sztuczna głębia w tej sztuce nie są nigdy stosowane $e^{42}$.

Ponieważ w Kościele wschodnim ikona ma rangę sakramentu, do wprowadzenia ikony w jej funkcję liturgiczną wymaga się pośrednictwa kapłana i obrzędu konsekracji. Obraz, którego poprawność dogmatyczna, zgodność z tradycją i wystarczający poziom wyrazu artystycznego zostały stwierdzo-

\footnotetext{
39 Por. P. Evdokimov, Sztuka..., dz. cyt., s. 189-191.

Por. tamże, s. 188.

Por. tamże, s. 162.

Por. tamże, s. 188.
} 
ne przez kapłana, staje się cudowną ikoną, przy czym określenie „cudowna” oznacza: wypełniona obecnością. Dlatego ikona jest niewątpliwym środkiem Bożej obecności i kanałem łaski prowadzącej do cnoty uświęcającej.

To właśnie ta liturgiczna teologia obecności, potwierdzona w obrzędzie poświęcenia, odróżnia ikonę od obrazu o tematyce religijnej i wyznacza między nimi granicę. Można powiedzieć, że każde dzieło czysto estetyczne składa się z trzech elementów, którymi są artysta, samo dzieło i obserwator. Artysta poprzez dzieło wywołuje w duszy widza pewną emocję. Jeżeli z emocji tej rodzi się uczucie religijne, to wypływa ono jedynie z subiektywnej zdolności widza do odczucia go. Dzieło sztuki istnieje po to, by na nie patrzeć, by zachwycać duszę; wzruszać i wzbudzać podziw, lecz nie są to funkcje sztuki liturgicznej ${ }^{43}$.

W sztuce zachodniej, szczególnie począwszy od epoki renesansu, dominował pogląd, że sztuki plastyczne należy traktować jako najwyższe czynności człowieka, wyprzedzające nawet słowo i rozumowanie. Nastąpiło znaczne poszerzenie zbioru motywów tematycznych oraz liberalizacja wymogów formalnych dotyczących przedstawień. Dzieła sztuki zależały jedynie od fantazji i sprawności warsztatowej malarza, a potrzeba akceptacji teologicznej i formalnej treści oraz jakości dzieł sztuki ze strony Kościoła została zminimalizowana. Miało to niebagatelny wpływ na oddalenie ikonografii Zachodu od wspólnego dziedzictwa ze Wschodem.

\section{Zakończenie}

W rozumieniu Wschodu być w stanie przebóstwienia to znaczy kontemplować światło niestworzone i pozwalać się mu przeniknąć. To oznacza również móc odtwarzać w sobie tajemnicę chrystologiczną: „Przez miłość połączyć naturę stworzoną i niestworzoną, ukazując je w jedności przez osiągnięcie łaski". Bóg wciąż ukryty w swojej istocie objawia się wielokrotnie i na różne sposoby, aby napełnić człowieka swoją bliskością.

Cała tajemnica ikony zawiera się w dynamicznym i niezwykłym podobieństwie do pierwowzoru, czyli do Chrystusa. Podobieństwo to musi być jednak potwierdzone przez Kościół, a więc przeżyte w sposób jednoczący.

${ }^{43} \quad$ Por. tamże, s. 157. 
Zgodnie z Tradycją Wschodu pierwsza ikona Chrystusa powstała jeszcze za Jego życia na ziemi. Było to odbicie twarzy Chrystusa na płótnie przesłane królowi Abgarowi, który błagał o zbawienie i zdrowie właśnie za pośrednictwem wizerunku Boskiego Oblicza ${ }^{44}$. Odpowiednikiem tych wydarzeń w Kościele zachodnim jest spotkanie Jezusa z Weroniką w trakcie Drogi Krzyżowej oraz wizerunek Syna Bożego odciśnięty na jej chuście. Są to tak zwane wizerunki nie ludzką ręką uczynione, czyli acheiropoietos.

Istota Boga rzeczywiście przekracza postrzeganie ludzkimi zmysłami, ale udział w chwale Bożej stanowi wiecznie trwające Boże zaproszenie nadające jasny cel, skierowane do człowieka, przemienionego dzięki wcieleniu oraz zbawczej męce i zmartwychwstaniu Syna Bożego ${ }^{45}$.

\section{The grace of icons}

The article brings the reality of the grace of icons in two respects: the first relating to the recipient and the second relating to the icon writer. Grace is the transforming reality "in the image and likeness of God". It is received through a recipient's personal prayer and life experience. The gift of writing icons, their reading and reception in a cultural context is also a grace. Knowledge and application of adequate painting techniques is included in the canon. Its aim is creating an appropriate image which is a true "window to another world', to a reality already divinized. Icons must therefore meet certain conditions in order to be adequately helpful in prayer. They must also bring truly its recipient closer to Divine Persons, biblical events or scenes from the lives of the saints. Over the centuries, from the very beginning of Christian sacred art, through the turbulent period of iconoclasm, up to the present day, icons have retained a fundamental importance in the eastern Church, becoming almost a sacrament. In the western Church they suffered profound transformation, taking the form of holy pictures. They are liberated from the canons and techniques, depending only on the artist's skills and fashions of the time. They play an assistant role in the liturgy and a decorative one in the architecture of temples.

Keywords: grace, icon, canon, iconoclasm

Słowa kluczowe: łaska, ikona, kanon, ikonoklazm

44 Por. L. Uspieński, Teologia ikony, tł. M. Żurowska, Poznań 1993, s. 23.

45 Por. K. Klauza, Teologiczna..., dz. cyt., s.162-163 